\title{
Detrimental Effect of Cell Phones and its Awareness among Adolescents in Selected Urban Community of Sikar City (Rajasthan)
}

\author{
Prof. (Dr.) Mahipal Singh ${ }^{1 *}$, Nilesh Soni ${ }^{2}$
}

${ }^{1}$ Professor \& Principal Akhil Bharati Vidyapeeth College of Nursing, Sikar Rajasthan, India

${ }^{2}$ Assistant professor Akhil Bharati Vidyapeeth College of Nursing, Sikar Rajasthan, India

DOI: $10.36347 /$ sasjm.2020.v06i09.001

| Received: 18.08.2020 | Accepted: 29.08.2020 | Published: 02.09.2020

*Corresponding author: Prof. (Dr.) Mahipal Singh

\section{Abstract}

Communication is essential in every area of life. The cellular telephone system is a way of providing portable telephor services. Cell phones are a vast improvement over the telecommunications technology of the past century, and are dead became a part of modern life. Cell phones have become a necessity for many people throughout the world but nothing without some detrimental effects. Such detrimental effects of cell phones on the youth may lead health risks such mental health and physical health problems; hence a study was conducted to assess the detrimental effects of cell phon and its awareness among adolescents. A structured interview schedule was used to determine the detrimental effects cell phones and its awareness among adolescents. Non Experimental uni-variant descriptive design is used on 10 adolescents from Urban Community of Sikar City. The technique used in the study is Non probability convenie sampling technique and it shows that out of 100 about half of the adolescent (48\%) were averagely aware, around 46 were poor awareness, and only $6 \%$ were fully aware about the detrimental effects of cell phones.

Keywords: Detrimental Effect, Adolescents, Cell Phones.

Copyright @ 2020: This is an open-access article distributed under the terms of the Creative Commons Attribution license which permits unrestricted use, distribution, and reproduction in any medium for non-commercial use (NonCommercial, or CC-BY-NC) provided the original author and source are credited.

\section{INTRODUCTION}

Technological advances have improved our health, the food we eat, the clothes we wear, how we travel, and how we communicate with one another. There are a few drawbacks to some aspects of technology but overall technology has greatly improved many aspects of living for most people.

Cell phones are a vast improvement over the telecommunications technology of the past, and are daily becoming a fixture of modern life cell phones have become a necessity for many people throughout the world. The ability to keep in touch with family, business associates, and access to email are only a few of the reasons for the increasing importance of cell phones. When cell phones were first introduced to the public, they were bulky, expensive, and some even required a base unit that had to be transported along with the phone.

The cell phone is a modern-day invention, which has managed to reach many parts of the world enabling telecommunications across areas where it was not possible before. In the year 2000, there were an estimated 500 million cell phone users worldwide.
Today, there are about 3.3 billion users [2]. The use of cell phones among young children and adolescents is also increasing dramatically. Although cell phones seem to be the ideal device for simplicity and connectedness, nothing is perfect. Therefore, nothing is without some negative effects. Such negative effects of cell phones on the youth are health risks such as mental health, bullying, eye strain and digital thumb, brain tumours and low sperm counts, lack of sleep and their addiction and no self- control in owning a cell phone.

\section{Need of the study}

In a report about health hazards of cell phones in Indian perspective, it is said that the cell phone industry has been one of the fastest growing industries in modern history. Today, India has million cell phone users, and cell phones account for $88 \%$ of all telecommunication users. The rural sector accounts for more than $25 \%$ of all wireless phone users and this proportion is bound to grow as affordability of cell phones continues to increase. Studies have demonstrated that usage behaviors', such as duration of usage and predominant, one-sided use of cell phones are some of the chief risks that increase likelihood of hazards resulting from cell phone use [13]. 


\section{Problem Statement}

Detrimental Effect of Cell Phones and Its Awareness among Adolescents in Selected Urban Community of Sikar City with Objectives of study are, to assess the detrimental effects of cell phones and its awareness among adolescents. Second objective is to find the association of awareness with selected demographic variables of adolescents.

\section{REVIEW OF LITERATURE}

Review of literature related to detrimental effect of cell phones and its awareness among adolescents

Panda NK, Jain R, et al. [13] a retrospective, cross-sectional, randomized, case control study was carried out in a tertiary care hospital, Chandigarh, India with an aim to assess the effects of chronic exposure to electromagnetic waves emitted from Global System for Cell Communication (GSM) cell phones on auditory functions. One hundred twelve subjects who were longterm cell phone users (more than 1 year) and 50 controls that had never used a cell phone underwent a battery of audio logic investigations including pure-tone audiometry (both speech and high frequency), tympanometry, distortion product otoacoustic emissions, auditory brain responses, and middle latency responses. Changes in the various parameters were studied in the cell phone- and non-cell phone-using ears of subjects and corresponding ears of the controls to ascertain the effects of electromagnetic exposure. Results showed that there was no significant difference between users and controls for any of the audio logic parameters. However, trends for audio logic abnormalities were seen within the users. Highfrequency loss and absent distortion product otoacoustic emissions were observed with an increase in the duration of cell phone use, excessive use of cell phones, and age more than 30 years. Researcher concludes that long-term and intensive cell phone use may cause inner ear damage.

Khan MM. et al. [10] a descriptive survey was conducted in Riyadh among 330 adolescents with an aim to investigate whether the symptoms of ill health reported by young people may be associated with the use of cell phone and to analyze its influence on health. The questionnaire was designed specifically for this study and contained items regarding health condition and health complaints as well as the frequency of cell phone use. The response rate was $86.6 \%$ (286 of 330 forms, completed by $73.77 \%$ males and $26.22 \%$ females). Result showed that most of the subjects $(83.57 \%)$ had some knowledge about the adverse effects of cell phone use. About $76.92 \%$ of the students carried one cell and $23.08 \%$ more than one. Nearly $55.94 \%$, of the subjects reported the average daily cell phone use of less than $30 \mathrm{~min}, 27.97 \%$, of 30-60 min, $11.53 \%$, of $60-90 \mathrm{~min}$ and $4.54 \%$ of more than $90 \mathrm{~min}$.
About $16.08 \%$ of the subjects complained of headache and $24.48 \%$ of fatigue. Impaired concentration was reported by $34.27 \%$ of respondents, memory disturbances by $40.56 \%$, and sleeplessness by $38.8 \%$, hearing problems by $23.07 \%$, and facial dermatitis by $16.78 \%$. The sensation of warmth within the auricle and behind/around the ear was reported by $28.32 \%$. Out of 286 subjects who participated in this study, 44.4\% related their symptoms to cell phone use. Research findings indicate that the use of cell phones may lead to a number of symptoms such as headache, impaired concentration and memory, and also fatigue.

Schlehofer MM, Thompson SC, et al. [16] conducted a survey was in USA among 69 college students to explore the psychological predictors of cell phone use while driving. College students predicted their driving performance both with and without a simultaneous phone conversation. Their actual performance on a driving simulator was then assessed. Cell phone use reduced performance on the simulation task. Further, perceiving oneself as good at compensating for driving distractions, overestimating one's performance on the driving simulator, and high illusory control predicted more frequent cell phone use while driving in everyday life. Finally, those who talked more frequently on a phone while driving had poorer real-world driving records.

\section{MATERIALS AND METHODS RESEARCH APPROACH}

The main aim of this study is to check the Detrimental Effect of Cell Phones and Its Awareness among Adolescents in order to achieve the objectives of this study; the method adopted was descriptive survey approach. Research design adopted is Non experimental uni-variant descriptive design in urban areas of Sikar city. Study was conducted from feb 2019 to june.2019 on 100 Adolescents In Urban Community Of Sikar City. Samples were selected by Non Probability convenient sampling.

\section{DATA ANALYSIS \& RESULTS}

The collected data is tabulated, analyzed, organized and presented under the following headings:

- Section I: analysis of demographic data by using frequency and percentage.

- Section II: analysis of data related to awareness regarding detrimental effect of cell phones among adolescents

- Section III: analysis of data to find the association of awareness with selected demographic variables of adolescents.

- Section I: analysis of demographic data by using frequency and percentage. 
Table-1: Description of demographic characteristics of adolescents

\begin{tabular}{|c|c|c|c|}
\hline S. No. & Demographic characteristics & Frequency & Percentage \\
\hline 1. & \multicolumn{3}{|l|}{ Age } \\
\hline & a. $10-13$ years & 18 & 18.0 \\
\hline & b. $14-16$ years & 32 & 32.0 \\
\hline & c. 17-19 years & 50 & 50.0 \\
\hline 2. & \multicolumn{3}{|l|}{ Gender } \\
\hline & a. Male & 60 & 60.0 \\
\hline & b. Female & 40 & 40.0 \\
\hline 3. & \multicolumn{3}{|l|}{ Education } \\
\hline & a. Primary \& Middle School & 14 & 14.0 \\
\hline & b. Secondary & 30 & 30.0 \\
\hline & c. Secondary \& above & 56 & 56.0 \\
\hline 4. & \multicolumn{3}{|c|}{ Source of information regarding ill effects of cell phones } \\
\hline & a. Mass media & 66 & 66.0 \\
\hline & b. Friends & 6 & 6.0 \\
\hline & c. Health professionals & 0 & 0 \\
\hline & d. No information & 28 & 28.0 \\
\hline
\end{tabular}

\section{MAJOR FINDINGS OF STUDY}

- Section I: Analysis of the demographic data

- The age wise distribution showed that most of the adolescents 50(50\%) were belongs to 17-19 years, $32(32 \%)$ were in the age group of 14-19 years, and $18(18 \%)$ of the subjects were belongs to $10-13$ years.

- Gender wise distribution of the subjects showed that majority $60(60 \%)$ were male and $40(40 \%)$ were female.

- In relation to the education majority of the subjects $56(56 \%)$ were from Secondary and above, 14(14\%) were from primary and middle school and 30 $(30 \%)$ were Secondary school.

- Majority $66(66 \%)$ adolescents got information through mass media, $6(6 \%)$ were got information through friends, $0(0 \%)$ were got information through other sources \& about $18(28 \%)$ did not get any information on Detrimental Effect of Cell Phones and none of the samples got any information from health professionals

- Section II: Analysis Of Data Related To Awareness Regarding Detrimental Effect Of Cell Phones Among Adolescents

Table-2: Percentage and frequency distribution of awareness regarding detrimental effect of cell phones Among adolescents $\mathrm{N}=\mathbf{1 0 0}$

\begin{tabular}{|l|c|c|}
\hline Level of knowledge & Number & Percentage (\%) \\
\hline Poor (0-40\%) & 46 & 46 \\
\hline Average (41-60\%) & 48 & 48 \\
\hline Good (61-80\%) & 6 & 6 \\
\hline Very good (81-100\%) & 0 & 0 \\
\hline Overall & $\mathbf{1 0 0}$ & $\mathbf{1 0 0}$ \\
\hline
\end{tabular}

Major Findings In table 2 depicts the awareness regarding detrimental effect of cell phones among adolescents, nearly half of the adolescent $(48 \%)$ were averagely aware, around $46 \%$ were poor awareness, and only $6 \%$ were fully aware about the detrimental effects of cell phones.

Table-3: Description of area wise mean, SD and mean \% of awareness score. $N=100$

\begin{tabular}{|c|l|c|c|c|c|}
\hline Sl. No. & Aspects of knowledge & $\begin{array}{c}\text { Max. possible } \\
\text { score }\end{array}$ & $\begin{array}{c}\text { Mean } \\
\text { score }\end{array}$ & SD & Mean \% \\
\hline 1. & Basic concepts of cell phones. & 5 & 2.76 & 0.771 & 55.20 \\
2. & Detrimental Effects of cell phones. & 12 & 4.26 & 2.601 & 35.50 \\
3. & Precautions for cell phone usage. & 8 & 3.16 & 1.822 & 39.50 \\
\hline & Total & 25 & 10.18 & 4.402 & 40.72 \\
\hline
\end{tabular}


Major Findings In table 3 revealed that the area wise mean score percentage on awareness of adolescents regarding detrimental effect of cell phones among adolescents reveals that highest mean percentage $(55.20 \%)$ was found in the area of awareness regarding "basic concepts of cell phones" with mean \pm SD of 2.76 \pm 0.77 . The mean percentage of awareness score in the area of "effects of cell phones" was $35.50 \%$ with mean $\pm \mathrm{SD}$ of $4.26 \pm 2.60$. In the area of "precautions for cell phone usage" the mean percentage was 39.50 with an area wise mean \pm SD of $3.16 \pm 1.82$. Analysis revealed that out of 25 maximum attainable score the total mean percentage $40.72 \%$ mean \pm SD of $10.18 \pm 4.40$.

Table-4: Item wise correct response of the adolescents in regards to Detrimental Effects of cell phones $\mathrm{N}=100$

\begin{tabular}{|c|c|c|c|}
\hline Sl. No. & Item & No. & $\%$ \\
\hline 1. & The excess use of cell phone leads to disturbance in sleep. & 28 & 28 \\
\hline 2. & Learning, memory \& movement are affected by excessive use of cell phones. & 60 & 60 \\
\hline 3. & The complication associated with excessive use of cell Phone is infertility. & 52 & 52 \\
\hline 4. & Long conservation in cell phones affects the mechanism of hearing. & 62 & 62 \\
\hline 5. & The use of cell phones during driving causes a risk of Accidents. & 62 & 62 \\
\hline 6. & $\begin{array}{l}\text { Microwave radiation of cell phone opens blood brain barrier of CNS \& causes damage to } \\
\text { brain cells. }\end{array}$ & 32 & 32 \\
\hline 7. & $\begin{array}{l}\text { During pregnancy excess exposure to cell phone affects the child by causing behavioural } \\
\text { problems. }\end{array}$ & 6 & 6 \\
\hline 8. & Disturbed sleep due to cell phone radiation may cause stress burnout. & 22 & 22 \\
\hline 9. & Posting text / image in cell phone intended to hurt / embarrass other is called bullying & 10 & 10 \\
\hline 10. & $\begin{array}{l}\text { Most commonly used chemical and metal components in cell phones which are harmful to } \\
\text { human and animals are calcium, nickel and mercury. }\end{array}$ & 2 & 2 \\
\hline 11. & The impact of cell phone usage in adolescents has lead to less face to face communication. & 42 & 42 \\
\hline 12. & $\begin{array}{l}\text { The complication of climatic changes due to cell phone Usage has caused rise in average } \\
\text { temperature of earth. }\end{array}$ & 48 & 48 \\
\hline
\end{tabular}

Major Findings In :- table 4 revealed that highest percentage $(62.0 \%)$ of awareness was observed for the item no. 9 "Long conservation in cell phones affects the mechanism of hearing" and the item no.10 "The use of cell phones during driving causes a risk of accidents". Least (2.0\%) awareness was observed for item no. 15 "Most commonly used chemical and metal components in cell phones which are harmful to human and animals are calcium, nickel and mercury".

Table 5: Item wise correct response of the adolescents with precautions for cell phone usage $\mathrm{N}=100$

\begin{tabular}{|c|c|c|c|}
\hline Sl. No. & Item & No. & $\%$ \\
\hline 1. & The precautionary information regarding cell phone use is don't use cell phones while charging. & 26 & 26 \\
\hline 2 & $\begin{array}{l}\text { The most effective preventive strategy to safeguard from cell is the use of headset/speaker phone } \\
\text { mode. }\end{array}$ & 52 & 52 \\
\hline 3 & The selection of the cell phone should be based on Specific Absorption Rate. & 2 & 2 \\
\hline 4 & $\begin{array}{l}\text { The risk of ignition in petrol bunks through cell phone use is caused due to flammable vapours by } \\
\text { radio signals. }\end{array}$ & 42 & 42 \\
\hline 13. & $\begin{array}{l}\text { The measure to prevent the damage of hearing mechanism due to cell phone use is don't stick to } \\
\text { long hour conversations. }\end{array}$ & 58 & 58 \\
\hline 14. & $\begin{array}{l}\text { The psychological effect like cell addiction, Insomnia can be prevented by minimum cell phone } \\
\text { usage. }\end{array}$ & 64 & 64 \\
\hline 15. & $\begin{array}{l}\text { Harmful effects on environment due to cell phone usage can be prevented by Proper disposal of } \\
\text { cell phones }\end{array}$ & 58 & 58 \\
\hline 16. & Cell phone use should be avoided in places like libraries \& hospital emergency rooms. & 14 & 14 \\
\hline
\end{tabular}

Major Findings in: table 5 revealed that the "the psychological effect like cell addiction, insomnia can be prevented by minimum cell phone usage" had good awareness. Whereas the Item "the most effective preventive strategy to safeguard from cell is the use of headset / speaker phone mode", item "the risk of ignition in petrol bunks through cell phone use is caused due to flammable vapors by radio signals", item "the measure to prevent the damage of hearing mechanism due to cell phone use is don't stick to long hour conversations" and item "harmful effects on environment due to cell phone usage can be prevented by proper disposal of cell phones" had average awareness. Item "the selection of the cell phone should be based on specific absorption rate" and item "cell phone use should be avoided in places like libraries \& hospital emergency rooms" had poor awareness.

- Section III: analysis of data to find the association of awareness with selected demographic variables of adolescents. 
Table-6: association of awareness with selected demographic variables of adolescents $\mathrm{N}=100$

\begin{tabular}{|l|l|c|c|c|}
\hline Sl. No. & \multicolumn{1}{|c|}{ Sample characteristics } & $<$ median & $\geq$ median & $\chi^{2}$ value \\
\hline 1. & Age in years & 12 & 14 & 0.081 \\
& $10-13$ & 10 & 14 & \\
& $14-16$ & 24 & 26 & \\
& $17-19$ & 30 & 30 & 0.483 \\
\hline 2. & Gender & 16 & 24 & \\
\hline 3. & Male & & & \multirow{2}{*}{0.19} \\
& Female & 10 & 12 & \\
& Education & 12 & 10 & \\
& Primary \& Middle & 24 & 32 & \\
& Secondary school & & & \\
& Secondary and above & & & \\
& Source of information regarding & 20 & 20 & \\
& ill effects of cell phones & 18 & 14 & \\
& Mass media & 0 & 0 & \\
& Friends & 8 & 20 & \\
& Health professionals & & & \\
& No information & & & \\
&
\end{tabular}

Table values: $\chi^{2}{ }_{1}=3.84, \mathrm{P}<0.05$

Major Findings In :- table 6 indicate that the chi square values of demographic variables like age, education and source of information regarding Detrimental Effects of cell phones were significant at 0.05 level of significance. Thus it is concluded that there was significant association between awareness score and the selected demographic variable such as age, education and source of information regarding detrimental Effects of cell phones.

Study is supported by similar study of Mumbai with the objectives to find the cell phone usage, purpose and the knowledge regarding the possible adverse effects on health as a part of market analysis. The study considered the demographic variables such as age, gender, income, duration of usage, education; type of living etc. The result had shown that there is significant association with the demographic variables education $\left(\chi^{2}=6.24\right)$, and income $\left(\chi^{2}=4.23\right)$. This finding is contradictory to the present study finding.

\section{CONCLUSION}

Detrimental effects of cell phones on the youth may lead health risks such as mental health and physical health problems; hence a study was conducted to assess the detrimental effects of cell phones and its awareness among adolescents. A structured interview schedule was used to determine the detrimental effects of cell phones and its awareness among 100 adolescents from Urban Community Of Sikar City with the help of Non Experimental descriptive design technique and its shows that out of 100 about half of the adolescent $(48 \%)$ were averagely aware, around $46 \%$ were poor awareness, and only $6 \%$ were fully aware about the detrimental effects of cell phones. This data could be used for health sector and policy maker to promote the better physical and mental health of youth.

\section{REFERENCES}

1. Abdella FG, Levine E. Better patient care through nursing research. $3^{\text {rd }}$ ed. New York: The Macmillan Publishing Company. 1979: 271.

2. Cell Phones Shown to Impact Male Fertility. [online]. Available from: URL: http://novaspivack.typepad.com/novaspivacks.weblog/2004/06/cell_phones.html. June 27, 2004.

3. Cell technologies Learning - cell communication. [online]. Available from: URL:www.networktutorials.info/cell-technology

4. Emerging aspects of cell phone use. [online]. Available from: URL:http://www.ehtforum.org/ehtj/journal/v2/pdf/ehtj09005a.pdf.

5. Hardell. Health Effects of Cell Phones: Recent Scientific and Policy Developments. [online]. Available from: URL:http://www.seas.upenn.edv/ kfoster/ cost 259/ htm.

6. http://en.wikipedia.org/wiki/Communications_in_I ndia.

7. http://www.hairydog.co.uk/cell 2.html

8. Introduction to cell phones. [online]. Available from: URL:www.chow.com

9. Kapdi M, Hoskote SS, Joshi SR. Health hazards of cell phones: an Indian perspective. J Assoc Physicians India. 2008 Nov;56:893-7.

10. Khan MM. Adverse effects of excessive cell phone use. Int J Occup Med Environ Health 2008;21(4):28993.

11. Khurana VG, Teo C, Kundi M, Hardell L, Carlberg M. Cell phones and brain tumours: a review including the long-term epidemiologic data. Surg Neurol. 2009 Sep;72(3):205-14.

12. Kundi M. The controversy about a possible relationship between cell phone use and cancer. Aus J Environ Health Perspect. 2009 Mar;117(3):316-24. 
13. Panda NK, Jain R, Bakshi J, Munjal S. Audiologic disturbances in long-term cell phone users. J Otolaryngol Head Neck Surg. 2010 Feb 1;39(1):511.

14. Rajpara A, Feldman SR. Cell phone allergic contact dermatitis: case report and review. Dermatol Online J. 2010 Jun 15;16(6):9

15. Sadetzki S, Chetrit A, Jarus-Hakak A, Cardis E, Deutch Y, Duvdevani S, etal. Cellular phone use and risk of benign and malignant parotid gland tumours - a nationwide case-control study. Am J Epidemiol 2008 Feb 15;167(4):457-67.

16. Schlehofer MM, Thompson SC, Ting S, Ostermann S, Nierman A, Skenderian J. Psychological predictors of college students' cell phone use while driving. Accid Annal Prev. 2010 Jul;42(4):1107-12.

17. Wdowiak A, Wdowiak L, Wiktor H. Evaluation of the effect of using cell phones on male fertility. Ann Agric Environ Med. 2007;14(1):169-72. 